DOI: 10.12731/wsd-2017-3-19-24

UDC 613.2

\title{
HYGIENIC ASSESSMENT OF FOODS QUALITY AND SAFETY WITHIN THE TERRITORY OF THE KHAKAS REPUBLIC ${ }^{1}$
}

\section{Kondrashova E.A.}

The paper presents the results of the research within the territory of the Khakas Republic of foods in terms of chemical safety indicators. The rate of non-oncogenic risk in relation to food consumption was determined as well as the analysis of alimentary-dependent diseases levels was carried out. A number of suggestions aimed at reducing dietary risk factors were made.

Keywords: foods; alimentary-dependent pathology rate; nitrates; chemical safety; risk assessment; contaminant exposure; danger coefficient.

\section{ГИГИЕНИЧЕСКАЯ ОЦЕНКА КАЧЕСТВА И БЕЗОПАСНОСТИ ПРОДУКТОВ ПИТАНИЯ НА ТЕРРИТОРИИ РЕСПУБЛИКИ ХАКАСИЯ}

\section{Кондрашова Е.A.}

В статье отражены результаты исследований на территории Республики Хакасия продуктов питания по показателям химической безопасности. Установлена величина неканцерогенного риска в связи с потреблением пищевых продуктов. Приведен анализ уровней алиментарнозависимой заболеваемости. Изложены предложения по снижению алиментарных факторов риска.

Ключевые слова: продукты питания; алиментарно-зависимая заболеваемость; нитраты; химическая безопасность; оценка риска; экспозиция контаминантом; коэффициент опасности.

${ }^{1}$ Кондрашова Е.А. Гигиеническая оценка качества и безопасности продуктов питания на территории Республики Хакасия // В мире научных открытий, 2016. № 3(75). С. 20-26. doi:10.12731/wsd-2016-3-2. 
Environment, diet as well as lifestyle are considered to be significant factors to affect public health. About $30 \%$ of the negative factors impact on public health comes from the impact of environmental factors. Foods quality and safety has a serious effect on public health [1, pp. 6-33; 3, pp. 4-10].

In 2010-2014 there was an increase in the alimentary-dependent diseases incidence rate within the territory of the Khakas Republic (Table 1).

Table 1 .

The alimentary-dependent diseases track record of all the residents of the Khakas Republic in 2010-2014 $\left(\%{ }_{000}\right)$

\begin{tabular}{|c|c|c|c|c|c|c|}
\hline \multirow{2}{*}{$\begin{array}{c}\text { Disease classes, disease sub- } \\
\text { classes, nosological entities }\end{array}$} & \multicolumn{5}{|c|}{ Period of monitoring } & $\begin{array}{c}\text { Growth rate } \\
\text { by } 2010 \\
\%\end{array}$ \\
\cline { 2 - 6 } & 2010 & 2011 & 2012 & 2013 & 2014 & 32.8 \\
\hline $\begin{array}{c}\text { Endocrine, nutritional and } \\
\text { metabolic disorders }\end{array}$ & 57.89 & 63.83 & 65.36 & 75.17 & 76.91 & 44.9 \\
\hline $\begin{array}{c}\text { Diseases of the blood and } \\
\text { blood-forming organs }\end{array}$ & 10.2 & 10.35 & 9.9 & 11.26 & 14.78 & 0.03 \\
\hline $\begin{array}{c}\text { Diseases of the circulatory } \\
\text { system }\end{array}$ & 212.23 & 212.39 & 207.63 & 217.14 & 212.30 & 0.9 \\
\hline Neoplasms & 33.8 & 35.41 & 38.41 & 38.23 & 38.50 & 13.9 \\
\hline
\end{tabular}

The largest increase among the alimentary-dependent pathology rate is observed in diseases of the blood and blood-forming organs $(44,9 \%)$, endocrine system diseases, nutritional and metabolic disorders $(32,8 \%)$.

The areas with the biggest number of cases of the blood and blood-forming organs diseases are as follows: Shirinsky district (14.7 per 1000 residents), Bogradsky district (14.8), the cities of Abakan (23.7) and Chernogorsk (16.1), whereas the average rate in the Khakas Republic is estimated within 11 to 14 per 1000 residents.

The following districts are among those that are characterized by a larger number of cases of the endocrine disorders compared to the average rate in the republic (2014: 76.9 per 1000 residents): Shirinsky district (125.5 per 1000 residents), Ordzhonikidzevsky district (99.3), Ust-Abakansky district (77.8), the city of Abakan (99.9) [2, pp. 61-65].

The purpose of the research is to analyse the foods quality within the territory of the republic in terms of the sanitary-chemical indicators in 2010-2014 as well as carry out risk assessment procedures related to foods consumption followed by a number of suggestions aimed at reducing the alimentary factors that affect the Khakas Republic residents. 
The object of the research is considered to be foods available at shops and public catering places.

The subject of the research is considered to be the foods safety sanitary-chemical indicators regulated by the unified sanitary, epidemiological and hygienic requirements for goods subject to sanitary and epidemiological supervision (control) approved by the Customs Union commission dated 28.05.2010 No 299 as well as technical guidelines of the Customs Union. The protocols of the tests carried out at the certified testing laboratory centre (Federal State-Funded Healthcare Institution 'Centre for Hygiene and Epidemiology of the Khakas Republic') over the period of 2010-2014 were used to assess the foods. Both the photometric and tetrametric research methods were applied. The statistics data processing was carried out with the use of the Microsoft Office Excel 2007 software. The descriptive statistics of the research results is presented by the relative indicators that include calculation of $95 \%$ confidence intervals. The calculation of foods contamination exposure in terms of the number of the residents was carried out using the median as well as the $90^{\text {th }}$ percentile of foods contamination rate $[4$, p. $3-20]$.

\section{Research results}

Having analysed the chemical contamination level in the foods, we have observed its fall by half over the period of 2012-2014 (3.4\% to 1.7\%). But despite the decrease, the contamination annual average rate in the Khakas Republic for 2014 is higher than the one in the whole territory of the Russian Federation, which amounted to $0.64 \%$.

The average chemical contamination rate for the period of 2012-2014 in the Khakas Republic amounts to 2.42(1.6-3.5)\%. The share of off-standard production samples for the above-mentioned period decreased from $9 \%$ to $4.69 \%$, the average rate being $4.62 \%(0.7-15.7)$ (Pic. 1).

The increase in the share of the samples that do not meet the above-mentioned requirements was observed in the produce group, including vegetables (1.82\% in 2010 to $3.99 \%$ in 2014).

The off-standard samples were found in the 6 administrative territories of the Khakas Republic, namely, in the cities of Chernogorsk and Sorsk as well as in Bogradsky, Ust-Abakansky, Tashtypsky, Ordzhonikidzevsky districts.

The main chemical contaminants are still thought to be nitrates, the average off-standard samples over the period of 5 years (2010-2014) being $9.2 \%$, while the average content rate of pesticides, arsenic, cadmium amounts to $0.2 \%$, the content of lead $-0.6 \%$, antibiotics $-2.6 \%$, whereas no mer- 
cury content was found in both foods and other type of produce over the above-mentioned period.

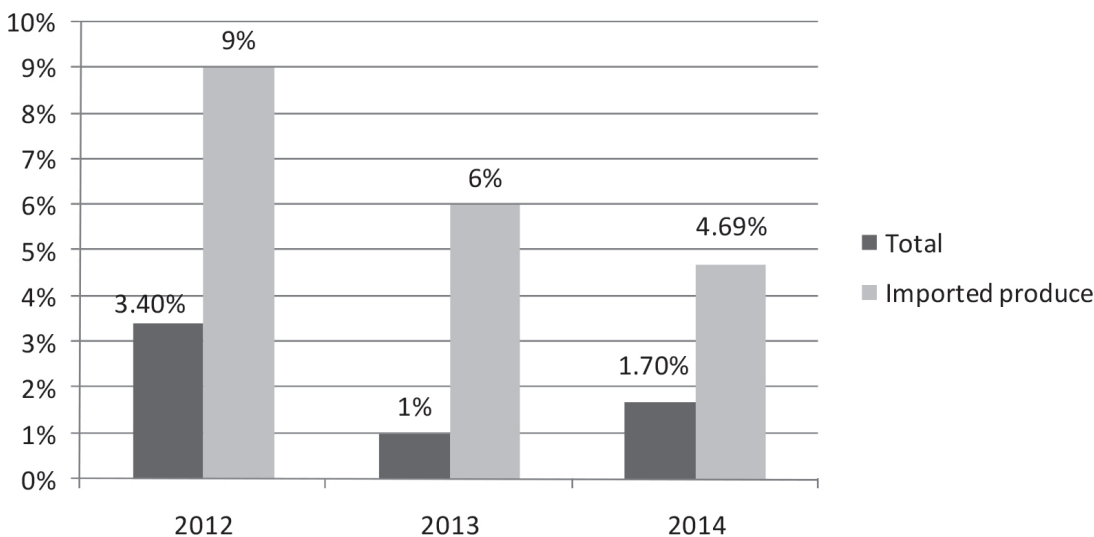

Pic. 1. Variation in the share of off-standard food samples

that do not meet the hygienic requirements in terms of the sanitary-chemicalindicators for the period of 2012-2014

Both domestic and imported produce fails to meet the standards in terms of nitrates content.

It is due to the fact that in the Khakas Republic the basic chemical contaminants in foods are nitrates found in fruit and vegetables, that the exposure assessment of these chemicals was made.

The contaminant exposure of the foods was made according to the formula:

$$
\operatorname{Exp}=\frac{\underset{i=1}{\operatorname{SUM}}\left(C_{i} \times M_{i}\right)}{B W},
$$

Exp - the contaminant exposure value, $\mathrm{mg} / \mathrm{kg}$ of the body weight $/ \mathrm{day}(\mathrm{mg} / \mathrm{kg}$

of the body weight/week, $\mathrm{mg} / \mathrm{kg}$ of the body weight $/$ month);

$C_{i}$ - contaminant content in i-product, $\mathrm{mg} / \mathrm{kg}$;

$M_{i}-i$-product consumption, $\mathrm{kg} / \mathrm{day}$ ( $\mathrm{kg} /$ week, $\mathrm{kg} /$ year);

$B W$ - human body weight, $\mathrm{kg}$ (standard value $-70 \mathrm{~kg}$ );

$N$ - total amount of the products used for the purposes of the research.

To calculate the risk of non-oncogenic impacts development the danger coefficient (HQ) was taken into consideration; the latter is expressed as the ratio between the assessed contaminant dose and permissible one according to the formulas: 


$$
\begin{gathered}
H Q_{\text {med }}=\frac{\mathrm{C}_{\text {med }}}{\mathrm{ADI}} \\
H Q_{90 \%}=\frac{E x p_{90 \%}}{\mathrm{ADI}}
\end{gathered}
$$

The produce consumption rate was established according to the budgetfunded research activities.

While calculating the foods contaminant exposure the data used were as follows: the standard human weight value $(70 \mathrm{~kg})$, median, $90^{\text {th }}$ percentile of nitrates content in the produce over the period of 2010-2014.

Table 2.

Exposure value and danger coefficient (HQ) for the residents of the Khakas Republic as nitrates are consumed orally along with the produce

\begin{tabular}{|c|c|c|}
\hline & $\begin{array}{c}\text { Contaminant exposure value (Exp), } \\
\mathrm{mg} / \mathrm{kg} \text { of the body weight/day }\end{array}$ & $\begin{array}{c}\text { Danger coefficient value } \\
(\mathrm{HQ})\end{array}$ \\
\hline $\mathrm{Me}$ & 0,69 & 0,18 \\
\hline $90^{\text {th }}$ percentile & 4,92 & 1,32 \\
\hline
\end{tabular}

\section{Conclusion}

Taking into consideration the research results obtained, the issue of providing the residents of the Khakas republic with high quality and contaminant-free foods seems to be one of the most pressing ones.

In order to ensure good nutrition of the residents of the Khakas republic in terms of its compliance with both sanitary and epidemiological standards, as well as to prevent contaminated and potentially off-standard foods being available on sale, it seems advisable to enhance the foods laboratory monitoring in research of contaminants.

For the aims of health maintenance and promotion, it is necessary to carry out an awareness-raising activities campaign among the residents of the republic providing information on healthy dieting, taking vitamin and mineral supplements to prevent alimentary-dependant disorders.

\section{References}

1. O sostoyanii sanitarno-epidemiologicheskogo blagopoluchiya naseleniya $v$ Rossiyskoy Federatsii v 2014 godu [About the state sanitary-epidemiological welfare of the population in the Russian Federation in 2014]. Moscow, 2015. 206 p.

2. O sostoyanii sanitarno-epidemiologicheskogo blagopoluchiya naseleniya $v$ Respublike Khakasiya v 2014 godu [On the state of sanitary-epidemiological 
welfare of the population in the Republic of Khakassia in 2014]. Abakan, 2015. $172 \mathrm{p}$.

3. Onishchenko G.G. O sanitarno-epidemiologicheskom sostoyanii okruzhayushchey sredy [The sanitary and epidemiological state of the environment]. Gigiena $i$ sanitariya [Hygiene and sanitation], 2013. no 2, pp. 4-10.

4. Opredelenie ekspozitsii $i$ otsenka riska vozdeystviya khimicheskikh kontaminantov pishchevykh produktov na naselenie. Metodicheskie ukazaniya. MU 2.3.7.2519-09 [Determination of exposure and assessment of risks of exposure to chemical contaminants in food products to the population]. $21 \mathrm{p}$.

\section{Список литературы}

1. О состоянии санитарно-эпидемиологического благополучия населения в Российской Федерации в 2014 году. М.: Федеральная служба по надзору в сфере защиты прав потребителей и благополучия человека, 2015. 206 с.

2. О состоянии санитарно-эпидемиологического благополучия населения в Республике Хакасия в 2014 году. Абакан: Управление Роспотребнадзора по Республике Хакасия, 2015. 172 с.

3. Онищенко Г.Г. О санитарно-эпидемиологическом состоянии окружающей среды // Гигиена и санитария. 2013. № 2. С. 4-10.

4. «Определение экспозиции и оценка риска воздействия химических контаминантов пищевых продуктов на население. Методические указания. МУ 2.3.7.2519-09» (утв. Роспотребнадзором 05.06.2009) 21 с.

\section{DATA ABOUT THE AUTHOR}

Kondrashova Ekaterina Aleksandrovna, Postgraduate Student, Department of Hygiene

Kemerovo State Medical Academy

22a, Voroshilova St., Kemerovo, Kemerovo Region, 650029, Russian Federation

kemsma@kemsma.ru

SPIN-code: 8189-3662

\section{ДАННЫЕ ОБ АВТОРЕ}

Кондрашова Екатерина Александровна, аспирант кафедры гигиены

Кемеровская государственная медицинская академия

ул. Ворошилова, 22 а, г. Кемерово, Кемеровская область, 650029, Российская Федерачия

kemsma@kemsma.ru 